\title{
Identification of Internal Factor Affecting Tourism Business Performance in Jembrana Regency of Bali
}

\author{
G K Gandhiadi ${ }^{1}$ \\ Mathematics Study Program of Udayana University of Indonesia \\ gandhiadi@unud.ac.id \\ I P Eka Nila Kencana ${ }^{2}$ \\ Mathematics Study Program of Udayana University of Indonesia \\ i.putu.enk@unud.ac.id
}

\begin{abstract}
The tourism industry in Jembarana Regency of Bali is currently still hobbling. Its contribution to the Jembrana Regional budget is still very minimal. Indeed accessibility to tourist destinations in Jembrana is often an obstacle for tourists, but internal factors that affect the performance of Jembrana tourism businesses are very important to be studied and analyzed, especially for tourism businesses actors and the role of government of the Jembrana Regency. Internal factors in tourism business are strongly influenced by the capacity of social capital, entrepreneurial culture of tourism actors and the role of the government in the development of tourism business. Based on a survey and structured interviews on 75 tourism entrepreneurs in Jembrana Regency of Bali, modeling by SEM-PLS with the help of Smart PLS 3.0 software, the results obtained are: (1) structural equation model has met the appropriate qualifications, the measurement model obtained is valid and reliable, while the structural model is quite good, (2) the performance of tourism businesses in Jembrana Regency is positively and significantly influenced by orientation entrepreneurship and the role of government but insignificant influence on social capital, and (3) internal factors that affect the performance of tourism businesses in Jembrana Regency of Bali; sequentially are: entrepreneurial orientation of business people, the role of government in tourism development, and finally the capacity of social capital owned by tourism entrepreneurs.
\end{abstract}

Keywords: Social Capital, Entrepreneurial Orientation, Role of Government, Tourism Business Performance

\section{BACKGROUND}

According to the Head of Tourism and Culture Office of Jembrana Regency, the development and success of the tourism sector in Jembrana Regency is not measured by the size of the Regional Original Income (PAD) obtained, but to what extent it can move the economy of the surrounding community (Berita Antara, 19 
April 2017). Even though the development of objects is getting better, where in 2016 there were 17 tourism objects in Jembrana, in 2017 this grew to 31 tourist attractions. In addition to physical facilities, the local government is growing entrepreneurial awareness for Human Resources (HR) both from the tourist destination managers and managers of tourism support facilities in Jembrana Regency.

Indeed accessibility to tourist destinations in Jembrana is often an obstacle for tourists, but internal conditions that affect the performance of Jembrana tourism businesses are very important to be studied and analyzed. The study of internal conditions in the business performance of an industry is largely influenced by the capacity of social capital, the entrepreneurial culture of actors and the role of the government in economic development, as well as the tourism sector. Social capital serves to overcome various kinds of collective barriers in a business field, including entrepreneurial orientation (Durlauf, 2005). Through the high capacity of social capital as well as can mprove the entrepreneurial orientation, and the positive role of government is expected to be able to improve the performance of tourism businesses in Jembrana Regency.

The relation between social capital and economic development has been widely studied, such as Putnam (1993), Colleman (1988) and Fukuyama (1999).The determining factor of the process of economic growth in development that is often overlooked is the way economic actors in interaction are strongly influenced by social capital (Vipriyanti, 2011). Each researcher has given different emphases and determinants about aspects of social capital in development.

Grouping of sources and dimensions of social capital is strongly influenced by the method of approach used in measuring social capital. Social capital is seen as a person's capacity to build networks based on prevailing norms and trust in others (Gandhiadi, 2017). In general there are three main groups of social capital, namely: (1) Trust, (2) Norms, and (3) Network.

The basic premise of the object of this research is social capital, the entrepreneurial orientation of tourism actors, and the role of government has a strong relevance to the outlook is expected to improve the performance of tourism businesses in Jembarna, Bali. It needs to be studied further, how is the internal factors of tourism businesses in Jembrana on their business performance. Emphasis in the field of mathematics on the object of this research is to examine the structural model or relationship using SEM (Structural Equation Modeling) based on variance, known as the SEM_PLS concept. 
This study aims to identification effect of internal factors, which is: social capital, entrepreneurial orientation, and government roles on the performance of tourism businesses in Jembrana Regency, Bali. The results of this study are expected to contribute in formulating development strategies in the tourism sector to improve the performance of tourism businesses in Jembrana Regency, Bali. Furthermore, this research is expected to be able to play a role in implementing the work program for the development of human resources (HR) in tourism by the Department of Tourism and Culture (Disparbud) of Jembrana Regency, Bali.

\section{MATERIALS AND METHODS}

Research data was taken at the tourism industry businesses and their supporters (tourist destinations, hotels and restaurants) in the Jembrana Regency, Bali Province. The selection of Jembrana Regency as the location (population) of this study was intentional (purposive) through consideration of tourism business activities in the relevant district. The number of samples is selected proportionally from each sub-district area and the sample unit is chosen randomly, except for the tourist destination area (DTW) all used as samples. A total of 75 businesses or supporters were selected as sample units. Determination of sample units with respondents in this study, including the leaders or managers of tourism businesses (not employees or tourists who were randomly selected from each district in the Jembrana Regency, Bali.

This study uses a questionnaire as an instrument to measure respondents' perceptions with the survey method through structured interviews with tourism businesses in Jembrana Regency, Bali. The results of the initial questionnaire obtained required a validity test (using product moment correlation test) and reliability testing (using Cronbach Alpha ( $\alpha$ ) technique), to test the feasibility level of the research instrument from the questionnaire used.

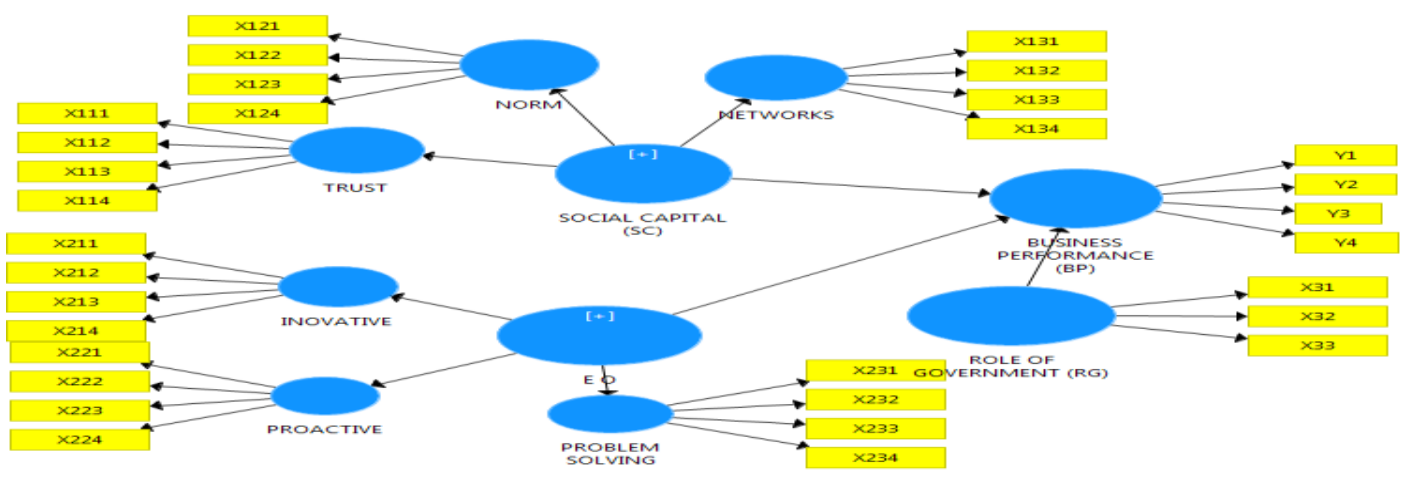

Figure 1. Design of structural equation model 
Based on the indicators used in accordance with the references of each construct (latent variables), structural equation models are designed such as Figure 1 and Table 1.

Table 1. Latent variables, indicators (question items)

\begin{tabular}{|c|c|c|}
\hline $\begin{array}{l}\text { Second Order of } \\
\text { Latent Variable }\end{array}$ & $\begin{array}{l}\text { First Order of } \\
\text { Laten Variable }\end{array}$ & Indicator (Item Question) \\
\hline \multirow[t]{3}{*}{$\begin{array}{l}\text { Social Capital (X1) } \\
\text { (Gandhiadi, 2017) }\end{array}$} & $\begin{array}{l}\text { Trust } \\
\text { (X11) }\end{array}$ & $\begin{array}{l}\text { X111: Most people care } \\
\text { X112: Trust in religious leaders } \\
\text { X113: Mutual trust in other employees } \\
\text { X114: Trust in other business friends }\end{array}$ \\
\hline & $\begin{array}{l}\text { Norm } \\
\text { (X12) }\end{array}$ & $\begin{array}{l}\text { X121: Harmony according to Tri Hitta Karana } \\
\text { X122: Compliance with existing rules } \\
\text { X123: Ease of finding capital assistance } \\
\text { X124: Ease of assistance in management } \\
\text { coaching }\end{array}$ \\
\hline & $\begin{array}{l}\text { Networks } \\
\text { (X13) }\end{array}$ & $\begin{array}{l}\text { X131: Working network density } \\
\text { X132: Collaboration with employees (bonding) } \\
\text { X133: Collaboration with fellow entrepreneurs } \\
\text { (bridging) } \\
\text { X134: Collaborate with other business friends } \\
\text { (linking) }\end{array}$ \\
\hline \multirow[t]{5}{*}{$\begin{array}{l}\text { Entrepreneurship } \\
\text { Orientation (X2) } \\
\text { (EO) } \\
\text { (Gandhiadi, 2017) }\end{array}$} & $\begin{array}{l}\text { Innovative } \\
\text { (X21) }\end{array}$ & $\begin{array}{l}\text { X211: Capability } \\
\text { X212: Persistence of new opportunities or } \\
\text { models } \\
\text { X213: Persistence } \\
\text { X214: High curiosity }\end{array}$ \\
\hline & $\begin{array}{l}\text { Proactive } \\
\text { (X22) }\end{array}$ & $\begin{array}{l}\text { X221: Active looking for consumers and } \\
\text { markets } \\
\text { X222: Proactively designing new products } \\
\text { X223: Proactive on market expansion } \\
\text { X224: Proactively raise support from other } \\
\text { parties }\end{array}$ \\
\hline & $\begin{array}{l}\text { Problem Solving } \\
\text { (X23) }\end{array}$ & $\begin{array}{l}\text { X231: Assertiveness; decisiveness } \\
\text { X232: Confident } \\
\text { X233: Systematic planning } \\
\text { X234: Dare to take decisions and risks }\end{array}$ \\
\hline & $\begin{array}{l}\text { Role of } \\
\text { Government } \\
\text { (X3) (Diva, } \\
\text { 2009) }\end{array}$ & $\begin{array}{l}\text { X31: Facilitator } \\
\text { X32: Catalyst } \\
\text { X33: Regulator }\end{array}$ \\
\hline & $\begin{array}{l}\text { Business } \\
\text { Performance } \\
\text { (Y) (Suci, 2009) }\end{array}$ & $\begin{array}{l}\text { Y1: Increased number of tourist visits } \\
\text { Y2: Increased type of tourism business } \\
\text { Y3: Increased tourism business income } \\
\text { Y4: Profitability }\end{array}$ \\
\hline
\end{tabular}




\section{RESULTS}

The results of the validity and reliability test of 31 initial questionnaires on indicators or statements used to measure the first-order latent variable (Corrected Item-Total Correlation) are all above 0.300, this means that all indicators are valid. Meanwhile, the value of Cronbach's Alpha $(\alpha)$ for each reflective latent variable is greater than 0.60 , this means that the indicator used to measure the construct is feasible and reliable (reliable) (Hanseler et al, 2009). Hence everything is valid and reliable, so the research can be continued to retrieve questionnaire data for 75 samples using all the indicators that have been compiled and then analyzed according to the data analysis stage.

Testing the measurement model (outer model) consists of a test: (1) convergent validity through the significance level of the path coefficients of each indicator, (2) the validity of discriminant validity through the Average Variance Extracted (AVE) value for each latent variable must be more size of 0.5 or significant in the level of certain statistical tests, and (3) composite reliability (composite reliability) through the Cronbach Alpha (CA:) and Composite Reliability (CR) values. An instrument said to be reliable if the Cronbach Alpha reliability coefficient or Composite Reliability is greater than 0.7 , but if the results obtained are close to 0.7 (eg 0.6), it can still be accepted in exploratory studies (Hanseler et al, 2009). The results of this reflective measurement model test were obtained after processing the research data for 75 respondents (samples) using Smart PLS 3.0 software tools, can be seen in Table 2 .

Table 3 shows the AVE values of each construct of more than 0.5 or significant in the 5 percent statistical test level, this means that all constructs used in this study have sufficiently valid. The Cronbach Alpha (CA) value of each construct is more than 0.6 or significant at the $5 \%$ t-test level (T-statistic value>1.96), so that each construct is reliable in the Cronbach Alpha test.

While the Composite Reliability (CR) value of each construct, it turns out that all constructs with a value of more than 0.7 means that they have also fulfilled the construct reliability requirements. Meanwhile all the indicators used in the study have a significant outer loading at the test level_t, 5 percent (T-Statistic $=1.96)$, where all indicators have a T_Values value greater than 1.96, as in Figure 2. 
Table 2. Results of Reflective Measurement Model Analysis

\begin{tabular}{|c|c|c|c|c|c|c|}
\hline $\begin{array}{l}\text { Construct } \\
\text { (Latent } \\
\text { Variable) } \\
\end{array}$ & AVE & CA ( $(\alpha)$ & $\mathbf{C R}$ & $\begin{array}{l}\text { Item } \\
\text { Code }\end{array}$ & $\begin{array}{c}\text { Outer } \\
\text { Loadin } \\
g\end{array}$ & $T$ - Statistic \\
\hline \multirow{4}{*}{ Trust } & \multirow{4}{*}{$\begin{array}{r}0,573 \\
(\mathrm{p}=0.00)\end{array}$} & \multirow{4}{*}{$\begin{array}{l}0,728 \\
(p=00)\end{array}$} & \multirow{4}{*}{$\begin{array}{r}0,836 \\
(p=0.00)\end{array}$} & $\mathrm{X} 111$ & 0,88 & $23,20(\mathrm{~s})$ \\
\hline & & & & $\mathrm{X} 112$ & 0,85 & $25,89(\mathrm{~s})$ \\
\hline & & & & X113 & 0,75 & $7,88(s)$ \\
\hline & & & & X114 & 0,46 & $2,81(\mathrm{~s})$ \\
\hline \multirow{4}{*}{ Norm } & \multirow{4}{*}{$\begin{array}{r}0,467 \\
(p=0.00)\end{array}$} & \multirow{4}{*}{$\begin{array}{r}0,590 \\
(p=0,00)\end{array}$} & \multirow{4}{*}{$\begin{array}{r}0,764 \\
(p=0.00)\end{array}$} & $\mathrm{X} 121$ & 0,85 & $30,66(\mathrm{~s})$ \\
\hline & & & & $\mathrm{X} 122$ & 0,61 & $4,29(\mathrm{~s})$ \\
\hline & & & & $\mathrm{X} 123$ & 0,80 & $11,41(\mathrm{~s})$ \\
\hline & & & & $\mathrm{X} 124$ & 0,36 & $2,17(\mathrm{~s})$ \\
\hline \multirow{4}{*}{ Networks } & \multirow{4}{*}{$\begin{array}{r}0,553 \\
(p=0.00)\end{array}$} & \multirow{4}{*}{$\begin{array}{c}0,733 \\
(p=0,00)\end{array}$} & \multirow{4}{*}{$\begin{array}{r}0,832 \\
(p=0.00)\end{array}$} & $\mathrm{X} 131$ & 0,67 & $5,27(\mathrm{~s})$ \\
\hline & & & & $\mathrm{X} 132$ & 0,75 & $12,71(\mathrm{~s})$ \\
\hline & & & & X133 & 0,74 & $10,52(\mathrm{~s})$ \\
\hline & & & & $\mathrm{X} 134$ & 0,80 & $16,58(\mathrm{~s})$ \\
\hline \multirow{3}{*}{ Social Capital } & \multirow{3}{*}{$\begin{array}{c}0,429 \\
(p=0,00)\end{array}$} & \multirow{3}{*}{$\begin{array}{r}0,869 \\
(p=0,00)\end{array}$} & \multirow{3}{*}{$\begin{array}{r}0,895 \\
(p=0,00)\end{array}$} & $X 11$ & 0,91 & $27,29(s)$ \\
\hline & & & & $X 12$ & 0,90 & $35,65(s)$ \\
\hline & & & & $X 13$ & 0,88 & $23,28(s)$ \\
\hline \multirow{4}{*}{ Innovative } & \multirow{4}{*}{$\begin{array}{r}0,507 \\
(p=0.00)\end{array}$} & \multirow{4}{*}{$\begin{array}{c}0,664 \\
(p=0,00)\end{array}$} & \multirow{4}{*}{$\begin{array}{r}0,799 \\
(p=0.00)\end{array}$} & $\mathrm{X} 211$ & 0,72 & $6,57(\mathrm{~s})$ \\
\hline & & & & $\mathrm{X} 212$ & 0,77 & $16,88(\mathrm{~s})$ \\
\hline & & & & X213 & 0,47 & $4,02(\mathrm{~s})$ \\
\hline & & & & X214 & 0,82 & $23,02(\mathrm{~s})$ \\
\hline \multirow{4}{*}{ Proactive } & \multirow{4}{*}{$\begin{array}{r}0,467 \\
(p=0.00)\end{array}$} & \multirow{4}{*}{$\begin{array}{c}0,702 \\
(p=0,00)\end{array}$} & \multirow{4}{*}{$\begin{array}{r}0,770 \\
(p=0.00)\end{array}$} & $\mathrm{X} 221$ & 0,82 & $18,75(\mathrm{~s})$ \\
\hline & & & & X222 & 0,47 & $2,93(\mathrm{~s})$ \\
\hline & & & & X223 & 0,58 & $6,08(\mathrm{~s})$ \\
\hline & & & & X224 & 0,80 & $15,54(\mathrm{~s})$ \\
\hline \multirow{4}{*}{$E O$} & \multirow{4}{*}{$\begin{array}{c}0,424 \\
(p=0,00)\end{array}$} & \multirow{4}{*}{$\begin{array}{c}0,868 \\
(p=0,00)\end{array}$} & \multirow{4}{*}{$\begin{array}{r}0,894 \\
(p=0,00)\end{array}$} & $X 21$ & 0,90 & $46,93(s)$ \\
\hline & & & & $X 22$ & & $33,21(s)$ \\
\hline & & & & $X 23$ & 0,87 & $12,54(s)$ \\
\hline & & & & & 0,94 & \\
\hline & & & & X31 & 0,89 & $36,62(\mathrm{~s})$ \\
\hline $\begin{array}{l}\text { Role of } \\
\text { Government }\end{array}$ & $\begin{array}{r}0,6 / 2 \\
(\mathrm{n}=000)\end{array}$ & 0,763 & $\begin{array}{r}0,860 \\
(\mathrm{n}=000)\end{array}$ & X32 & 0,78 & $8,26(s)$ \\
\hline & & $(\mathrm{p}=0,00)$ & & X33 & 0,76 & $10,53(\mathrm{~s})$ \\
\hline & & & & Y1 & 0,71 & $11,07(\mathrm{~s})$ \\
\hline & 0,694 & 0,849 & 0,900 & $\mathrm{Y} 2$ & 0,84 & $17,47(\mathrm{~s})$ \\
\hline Performance & $(p=0.00)$ & $(\mathrm{p}=0,00)$ & $(p=0.00)$ & Y3 & 0,85 & $20,95(\mathrm{~s})$ \\
\hline & & & & Y4 & 0,91 & $37,42(s)$ \\
\hline
\end{tabular}

Note: "s" means significant at the 5\% test level

Source: Primary Data (2018) 


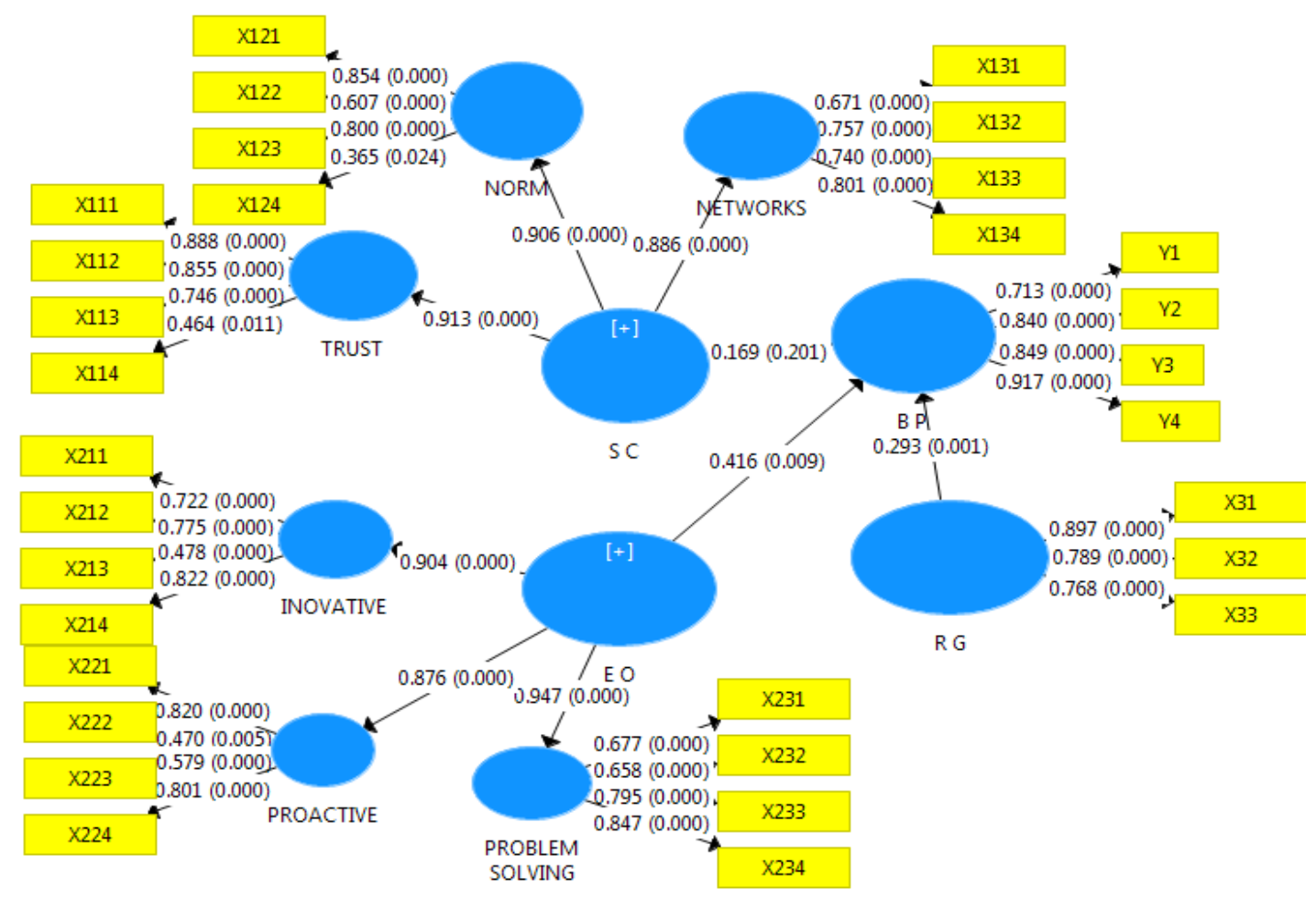

Figure 2. Path Analysis with Values of T_Statistic

Therefore testing the measurement model (outer model) all meet the requirements, meaning that all indicators and constructs in this study are valid and feasible to use for analysis on the structural model (inner model).

The structural model (inner model) is evaluated using the R-square for the dependent variable (endogenous) and the significant value is tested based on the value of $\mathrm{T}$-values in each path (path). Inner model testing relates to seeing the relationship between latent constructs by analyzing path coefficient estimation results and their level of significance.

The R-square for endogenous variables is the business performance construct of 0.601 (moderate structural model (Gotz et al, 2011). This means that the construct variability in the performance of tourism businesses in Jembrana Regency can be explained (influenced) by the constructs of social capital, entrepreneurial orientation and the role of government by 60.1 percent, while the remaining 39.9 percent is explained by other factors. It can be said that internal factors (social capital, entrepreneurial orientation and the role of government) are able to contribute in measuring the improvement of tourism business performance in Jembrana Regency 
by 60.1 percent, while as much as 39.9 percent is influenced by other factors (it could be influenced by factors external).

The structural model equation for the estimation of endogenous constructs (tourism business performance) which is influenced by exogenous constructs (social capital, entrepreneurial orientation and the role of government) according to Figure 2, can be formulated as follows.

Business Performance $=0.169 *$ Social Capital $+0.416 *$ Entrepreneurial Orientation $+0.293 *$ Role of Government + Error

\section{DISCUSSIONS}

The total or direct effect is expressed by the coefficients of all exogenous construct paths (Figure 2) with one end, at the level of significance through the T_Statistic test or $\mathrm{P}_{-}$Values 5 percent. The path coefficient that leads to the endogenous construct (business performance) and its significance states the performance conditions of the tourism businesses in Jembrana Regency towards internal factors (exogenous constructs: social capital, entrepreneurial orientation and the role of government) that influence it, as shown in Table 3

Table 3. Total Effects

\begin{tabular}{cccccc}
\hline Relationship & $\begin{array}{c}\text { Original } \\
\text { Sample }\end{array}$ & $\begin{array}{c}\text { Standard } \\
\text { Deviation }\end{array}$ & $\begin{array}{c}\boldsymbol{T} \\
\text { Statistics }\end{array}$ & $\begin{array}{c}\boldsymbol{P} \\
\text { Values }\end{array}$ & Note \\
\hline $\mathrm{X}_{1}(\mathrm{SC}) \rightarrow \mathrm{Y}(\mathrm{BP})$ & 0,169 & 0,129 & 1,308 & 0,191 & $\begin{array}{c}\text { Not } \\
\end{array}$ \\
& 0,416 & 0,155 & 2,679 & 0,008 & $\begin{array}{c}\text { Significant } \\
\text { Significant }\end{array}$ \\
$\mathrm{X}_{2}(\mathrm{EO}) \rightarrow \mathrm{Y}(\mathrm{BP})$ & 0,293 & 0,095 & 3,104 & 0,002 & Significant \\
& & & & & \\
\hline
\end{tabular}

Source: Primary Data (2018)

Table 3 shows the total effect between research variables (construct) business performance (BP) in the structural model are all positive and significant at the 5 percent test level, except the social capital (SC) construct which is insignificant. In general, the exogenous construct of social capital (SC), entrepreneurial orientation (EO) and the role of government (RG) have a positive effect on the endogenous construct of business performance (BP). The highest influence component of business performance (BP) is shown by the entrepreneurial orientation (EO) of 0.416 , then the role of government (RG) of 0.293 which both have a significant effect, and the last social capital (SC) is 0.169 which apparently has no significant effect. 


\section{CONCLUSIONS}

1) The measurement model obtained is valid and feasible, while the structural model is quite good (moderate) with a coefficient of determination of 0.601 . The structural equation model obtained is, Business Performance $=0.169 *$ Social Capital +0.416 $*$ Entrepreneurial Orientation $+0.293 *$ Role of Government + Error.

2) Internal factors, including social capital, entrepreneurial orientation and the role of government have a positive effect on the performance of the tourism industry business in Jembrana Regency, Bali. Factors of entrepreneurial orientation and the role of government have a significant effect on business performance, while social capital factors have no significant effect. It is also necessary to empower the capacity of social capital of tourism business actors in Jembrana Regency in improving their business performance, in addition to the entrepreneurial orientation factor of business actors and the role of government.

3) Domination of internal factors that affect the performance of tourism businesses in Jembrana Regency, Bali; are as follows: entrepreneurial orientation of business people, the role of government in tourism development, and finally the capacity of social capital owned by tourism businesses.

\section{RECOMMENDATION}

1) Entrepreneurial orientation of tourism entrepreneurs in Jembrana Regency really needs to be developed through training efforts by inviting tourism experts so that the entrepreneurial culture of the perpetrators increases.

2) The role of local governments, especially the Department of Tourism and Culture of Jembrana Regency, needs to be initiated continuously through the promotion or holding of special events to improve the performance of tourism businesses in Jembrana Regency, Bali.

3) The social capital capacity of tourism businesses actors in Jembrana Regency is actually high, so this needs to be empowered so that it can play a role in improving the performance of tourism businesses in Jembrana Regency, Bali.

\section{ACKNOWLEDGEMENT}

The author would like to thank Udayana University, especially to the Institute for Research and Community Service and the Faculty of Mathematics and Natural Sciences for founding this research based on the Work Agreement Letter for the 
Implementation of the Leading Research Program in 2018, No.2017 / UN14.2.8 / LT / 2018, March 26, 2018.

\section{REFERENCES}

Coleman J S. 1988. Social Capital in The Creation of Human Capital. American Journal of Sociology, Volume 94; pp 95-120. (DOI : https://doi.org/10.1086/228943)

Diva, Gede. 2009. Mengembangkan UKM Melalui Pemberdayaan Peran Pemerintah Daerah. Jakarta: Bakrie School of Management

Durlauf, S N and Fafchamps, M. 2005. Social Capital. In: Philippe Aghion and Steven N. Durlauf, Handbook of Economic Growth, Volume 1B. University of WisconsinMadison. pp 1640-1699. Fukuyama. 2000. Social Capital and Civil Society. Institute of Public Policy. George Mason University. (DOI : 10.5089/9781451849585.001)

G K Gandhiadi, I K Sudibia, I M Suyana Utama I A Saskara. 2017. The Influence of Social Capital on Subjective Wellbeing: A Structural Model for The Weaving Industry in Bali Province of Indonesia. International Journal of Economics, Commerce \& Management (IJECM), Volume 5(6); pp 216-230.

Gotz, O., Gobbers, K.L. \& Krafft, M., 2010. Evaluation of Structural Equation Models Using the Partial Least Squares (PLS) Aproach. Handbook of Partial Least Squares, pp.691711.

Henseler, J., Ringle, C.M. \& Sinkovics, R.R., 2009, The Use Of Partial Least Squares Path Modeling In International Marketing. Advances in International Marketing Journal, Vol.20, pp.277-319.

Jaya,I.G.N.M. \& Sumertajaya, IM.2008. Pemedelan Persamaan Struktural dengan Partial Least Square. Prosiding Seminar Nasional Matematika dan Pendidikan Matematika I, pp 118-132.

Putnam R D. 1993. Making Democracy Work : Civic Tradition in Modern Italy. Princeton University Press. Princeton.

Suci, R.P. 2009. Peningkatan Kinerja Melalui Orientasi Kewirausahan, Kemampuan Manajemen, dan Strategi Bisnis (Studi Kasusu pada Industri Kecil Menengah Bordir di Jawa Tengah. Jurnal Manajemen dan Kweirausahaan. Vol 11, No.1. Hal 46-58.

Vipriyanti, Nyoman Utari, 2011, Modal Sosial dan Pembangunan Wilayah : Mengkaji Succes Story Pembangunan di Bali, Penerbit Universitas Brawijaya (UB) Press. 